\title{
CHARACTERIZATION OF Exserohilum turcicum INFECTION SITES IN MAIZE GENOTYPES $^{1}$
}

\author{
JOSÉ RENATO STANGARLIN ${ }^{2}$, ELOISA LORENZETTI TARTARO ${ }^{3 *}$, SÉRGIO FLORENTINO PASCHOLATI ${ }^{4}$
}

\begin{abstract}
Northern leaf blight caused by Exserohilum turcicum is an important disease of maize (Zea mays L.), and its severity depends more closely on growth lesions than on spot number. Here, we characterized the infection sites of E. turcicum on resistant and susceptible maize genotypes by analyzing the histology of lesions as well as the structural and biochemical mechanisms of infection. Maize leaves were inoculated with the pathogen at specific points and incubated in a microhumidity chamber. Samples were obtained to follow fungal development and host tissue lignification using light and electron microscopy, and the activity and electrophoretic patterns of peroxidases were determined. The time course of spore germination and appressorium formation was essentially the same for both genotypes; however, a delay of $12 \mathrm{~h}$ in fungal penetration, accompanied by host tissue lignification, was noted in the resistant genotype, as opposed to that in the susceptible one. Scanning electron microscopy revealed fungal mycelium in the xylem vessels of both genotypes; however, in the resistant genotype, pathogen colonization was restricted to mesophyll cells around the penetration point, where chlorotic flecks were produced. Meanwhile, in the susceptible genotype, following penetration and chlorotic fleck formation, the pathogen continued to grow inside the xylem vessels and profusely colonized mesophyll tissue distant from the penetration point, resulting necrotic lesion development. Electrophoretic patterns of peroxidases were similar between the two genotypes, with three isoenzymes present in all tissues. In addition, two novel isoenzymes were detected in chlorotic flecks, necrotic lesions, and green tissue around the lesions.
\end{abstract}

keywords: Structural mechanisms. Resistance induction. Zea mays L.

\section{CARACTERIZAÇÃO DE LOCAIS DE INFECÇÃO DE Exserohilum turcicum EM GENÓTIPOS DE MILHO}

RESUMO - A mancha foliar causada por Exserohilum turcicum é uma importante doença em milho, cuja severidade depende mais do crescimento da lesão do que do número. O objetivo deste trabalho foi caracterizar sítios de infecção de E. turcicum em milho resistente e suscetível com base em análises histológicas, mecanismos estruturais e bioquímicos. As folhas foram inoculadas em pontos específicos utilizando microcâmara de inoculação. Foram coletadas amostras para acompanhar o desenvolvimento fúngico e lignificação utilizando microscopias ótica e eletrônica de varredura (MEV), além da atividade específica e padrão eletroforético de peroxidase. Os tempos de germinação de esporos e formação de apressórios foram praticamente iguais para os genótipos suscetível e resistente, no entanto, com relação à penetração, houve um atraso de $12 \mathrm{~h}$ no genótipo resistente, acompanhada pela lignificação do tecido hospedeiro, o que não ocorreu no genótipo suscetível. A análise por MEV mostrou micélio nos vasos do xilema em ambos os genótipos, entretanto, no resistente, a colonização do patógeno foi restrita às células do mesófilo ao redor da área de penetração, onde foram produzidos pontos cloróticos. No genótipo suscetível, após a penetração e formação de manchas cloróticas, o patógeno continuou crescendo dentro dos vasos do xilema e foi capaz de colonizar o tecido do mesófilo distante da área de penetração, dando origem a lesões necróticas. O padrão eletroforético de peroxidases foi semelhante nos dois genótipos, com três isoenzimas em todos os tecidos amostrados. Duas novas isoenzimas foram detectadas em pontos cloróticos, lesões necróticas e tecido verde em torno das lesões.

Palavras-chave: Mecanismos estruturais. Indução de resistência. Zea mays L.

\footnotetext{
${ }^{*}$ Corresponding author

${ }^{1}$ Received for publication in $06 / 03 / 2020$; accepted in 08/24/2021.

Paper extracted from the first author's master's thesis.

${ }^{2}$ Department of Agronomy, Universidade Estadual do Oeste do Paraná, Marechal Cândido Rondon, PR, Brazil; jose.stangarlin@unioeste.br - ORCID: 0000-0001-8601-9439.

${ }^{3}$ Department of Agricultural Sciences, Universidade Federal do Paraná, Palotina, PR, Brazil; eloisa-lorenzetti@hotmail.com - ORCID: 0000-0002-2363-2065.

${ }^{4}$ Department of Agronomy, Escola Superior de Agricultura Luiz de Queiroz, Universidade de São Paulo, Piracicaba, SP, Brazil; sfpascho@usp.br - ORCID: 0000-0002-9690-9694.
} 


\section{INTRODUCTION}

Maize (Zea mays L.) is one of the most important crops in the world because of its use as food for humans and other non-human animals. According to the Food and Agriculture Organization of the United Nations (2020), Brazil is the world's second largest exporter of corn. In the 2019/2020 harvest, the total domestic production reached 102.3 million tons in an area under the cultivation of 18.5 million hectares, with expected average productivity of 5,527 kg ha' ${ }^{-1}$ (CONAB, 2020).

The phytosanitary quality of crops is important for achieving good productivity indices. Exserohilum turcicum (Pass.) K. J. Leonard and E. G. Suggs, Cercospora zeae-maydis (T. Daniels), Pantoea ananatis-Phaeosphaeria maydis complex (P. Henn.), Stenocarpella macrospora (Earle) Sutton, Puccinia polysora Underw, and Puccinia sorghi Schw (CARVALHO; PEREIRA; CAMARGO, 2016) are the major phytopathogens detected on corn leaves.

Exserohilum leaf spot is a disease of great importance. As such, during an epidemic, the disease incidence may read $100 \%$, leading to drastic reduction in grain yield (RAMATHANI et al., 2011). Therefore, the fungus causing this disease is of great significance in corn production. Occurring in all maize-producing regions of Brazil and other global crop-growing areas, this fungus represents a major threat to the Brazilian crop (ALTAF et al., 2016).

Exserohilum leaf spot manifests as elliptical and elongated necrotic lesions, ranging in length from 2.5 to $15 \mathrm{~cm}$. Upon staining, the lesions appear grayish-green to brown in susceptible genotypes (COSTA; SILVA; COSTA, 2013). In resistant and moderately resistant genotypes, responses may vary from the lack of visible symptoms to the presence of lesions appearing as chlorotic, non-expanding spots, small circular necrotic-chlorotic lesions, or oval to elongated, expanding lesions (FERGUSON; CARSON, 2007). Thus, maize genotypes resistant or susceptible to E. turcicum may be characterized based on infection sites, represented by different types of lesions, according to the compatibility or incompatibility of the pathogen-host interaction.

Leaf spot and rust follow different epidemiological trends regarding the occupancy of infection sites on host leaves. Rush progresses through the appearance of new lesions (PIRES; FERNANDES; NICOLAU, 2009), whereas leaf spot progresses mainly through increase in the size of the existing lesions (BERGER; BERGAMIN FILHO; AMORIM, 1997). Thus, the rate of expansion of the lesion is an important component in the epidemiological process of leaf spot and has been used to determine the genetic resistance of the host (MENEGON; FORCELINI; FERNANDES, 2005).

Several plant defense mechanisms, characterized as passive (constitutive) or active (inducible) resistance factors and involving both structural or biochemical elements (STANGARLIN et al., 2011), may be linked to the host interactions with the pathogen at the infection sites. All these mechanisms, acting synergistically and coordinately, allow the plant to defend itself against pathogen attack through diverse responses to various pathogen -host interactions. Even within the same interaction, these responses may vary as a function of plant age, affected organ or tissue, nutritional status, and environmental conditions (PASCHOLATI; DALIO, 2018), or in an already established infectious process, they are initiated from the moment defense mechanisms start acting against the pathogen.

However, in the case of the interaction between $E$. turcicum and maize, one of the obstacles in conducting studies aimed at characterizing the infection site is the difficulty of observing symptoms from the inoculation point, as the lesions typically arise in places distant from the point of inoculum deposition. This fact raises questions regarding the initial stages of the infectious process of E. turcicum, wherein symptomatology related to the size and/or number of lesions has been implied.

To this end, we hypothesized that E. turcicum penetrates the leaf and uses the xylem vessels to colonize parts distant from the point of infection, thus circumventing the plant defense system. To test this hypothesis, we characterized E. turcicum infection sites on corn leaves by analyzing the histology of infectious lesions as well as the structural (lignification) and biochemical (peroxidase activity) mechanisms of infection. Furthermore, we examined differences in defense responses between maize genotypes resistant and susceptible to this fungus.

\section{MATERIAL AND METHODS}

\section{Plant material}

All experiments were performed under controlled environmental conditions at the Department of Phytopathology of ESALQ/USP. Maize lines susceptible (F64A) and resistant (F352) to E. turcicum (Agroceres) were used. Pregerminated seeds were used to maximize the emergence rate and ensure plant uniformity. In brief, seeds were surface sterilized by immersion in $1 \%$ sodium hypochlorite solution for $10 \mathrm{~min}$, following rapid immersion in $70 \%$ ethanol. The sterilized seeds were then soaked in distilled water at $25^{\circ} \mathrm{C}$ for hydration. After $18 \mathrm{~h}$, the seeds were transferred to a Gerbox containing a filter paper moistened with distilled water and incubated for 2 days at $25^{\circ} \mathrm{C}$ in the dark for germination. The pre-germinated seeds were placed in aluminum pots containing a mixture of soil and organic matter $(2: 2, \mathrm{v} / \mathrm{v} ; 1.5 \mathrm{~L})\left(120^{\circ} \mathrm{C}\right.$ and $1 \mathrm{~atm}$ for $1 \mathrm{~h}$ ) and placed in a growth chamber at

Rev. Caatinga, Mossoró, v. 35, n. 1, p. 1 - 13, jan. - mar., 2022 
a constant temperature of $25^{\circ} \mathrm{C}$ under $14 \mathrm{~h}$ of light for 14 days.

\section{Fungal culture and inoculation}

E. turcicum (AB2F7D1; SisGen) was obtained from the lesions on naturally infected corn leaves. The fungus was grown in lactose-hydrolyzed casein $(\mathrm{LCH})$ culture medium at $28^{\circ} \mathrm{C}$ in the dark for 14 days. Conidia were obtained by washing the fungal plugs with distilled water containing Tween 20 (1 drop in $300 \mathrm{~mL}$ ), and the spore density was adjusted to $5 \times 10^{1}, 5 \times 10^{2}, 5 \times 10^{3}$, or $5 \times 10^{4}$ conidia $\mathrm{mL}^{-1}$. The conidial suspensions were sprayed (DeVilbiss) on the entire area of the fourth leaf of 14 day old corn plants $\left(2.0 \mathrm{~mL}\right.$ suspension $\left.\cdot \mathrm{leaf}^{-1}\right)$. The inoculated plants were maintained in a humid chamber in the dark for $20 \mathrm{~h}$ and then under $14 \mathrm{~h}$ of light at $22^{\circ} \mathrm{C}$. Following the emergence of the first symptoms, the number and size of the lesions were evaluated every $24 \mathrm{~h}$.

Simultaneously with plant inoculation, an in vitro germination test of the conidia was performed.
Specifically, the conidial suspension was sprayed on a microscopy slide containing $2 \mathrm{~mL}$ of $1 \%$ agar-agar. The slide was placed in a Petri dish, with cotton soaked in distilled water, and incubated in the dark at $22^{\circ} \mathrm{C}$ for $20 \mathrm{~h}$. Fungal growth was inhibited using cotton blue lactophenol, and the germinated conidia were counted under an optical microscope.

Furthermore, lesion growth on the fourth leaf was evaluated using an inoculation microchamber (BERGSTROM; NICHOLSON, 1983) (Figure 1). Briefly, the inoculum $\left(1 \times 10^{4}\right.$ conidia $\left.\mathrm{mL}^{-1}\right)$ was placed in three alternating wells $(20 \mu \mathrm{L}$ spore suspension per well), and the wells were sealed with adhesive tape to maintain moisture. After $24 \mathrm{~h}$ in the dark, the inoculation microchambers were removed, and the plants were maintained under $14 \mathrm{~h}$ of light at a constant temperature of $25^{\circ} \mathrm{C}$. Following the emergence of the first symptoms, the number and size of the lesions were evaluated every $24 \mathrm{~h}$. Points that were isolated from the rest, such that they would not coalesce with other points upon development, were selected, and their growth was monitored daily.

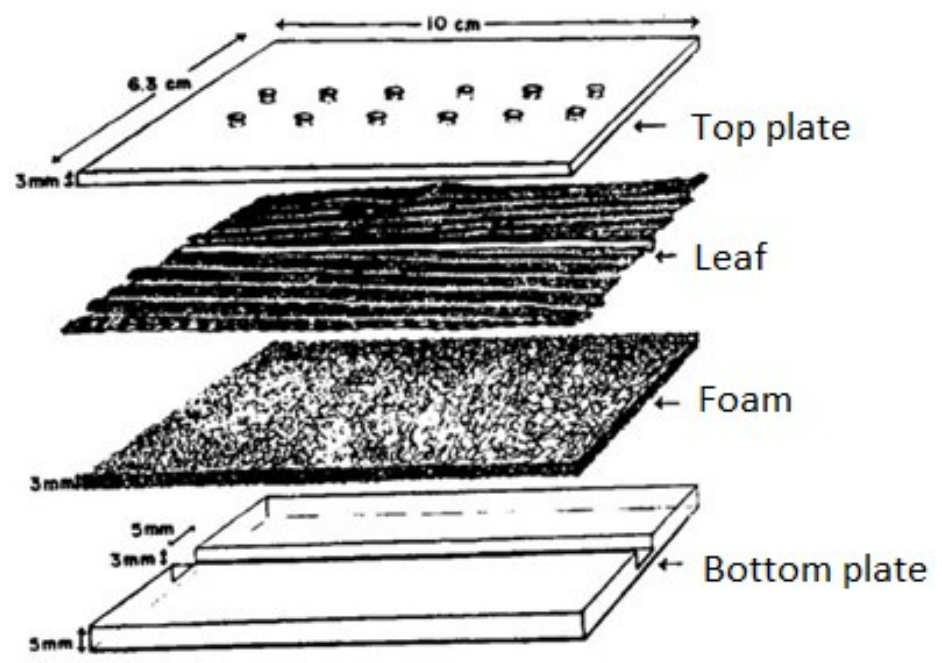

Figure 1. Schematic representation of the inoculation microchamber (adapted from Bergstrom and Nicholson (1983)).

At different time intervals after inoculation, samples were obtained from leaves (discs with a diameter of $1 \mathrm{~cm}$ ) and placed on microscopy slides with cotton blue lactophenol. Conidial germination, appressorium formation, fungal penetration, and fungal colonization of host tissues were observed under an optical microscope (STANGARLIN; PASCHOLATI, 1994).

\section{Peroxidase activity}

To analyze peroxidase activity, approximately $30 \mathrm{mg}$ of fresh tissue was used, collected at 12 days after pathogen inoculation and representing the following leaf regions: healthy tissue of uninoculated leaves (AS), green tissue distant from the lesions and/or chlorotic spots (TV), chlorotic spots (CP), necrotic lesions (LE), and green tissue adjacent (in $2 \mathrm{~mm}$ wide region) to the necrotic lesions (HA). Tissues from the mid-third of the inoculated leaves were also collected at $0,3,6,9,12,15,18,24,36$, 48,72 , and $120 \mathrm{~h}$ after inoculation.

The samples were homogenized in $4 \mathrm{~mL}$ of $0.01 \mathrm{M}$ phosphate buffer ( $\mathrm{pH}$ 6.0) (extraction buffer) in a porcelain mortar. The homogenate was centrifuged at $20,000 \times g$ for $25 \mathrm{~min}$. The supernatant 
was considered the fraction containing soluble peroxidases and stored at $4{ }^{\circ} \mathrm{C}$ for further analyses of enzyme activity and protein content.

Peroxidase activity was determined using direct spectrophotometry (HAMMERSCHMIDT; NUCLES; KUC, 1982). The reaction mixture comprised $2.9 \mathrm{~mL}$ of a solution containing $250 \mu \mathrm{L}$ of guaiacol and $306 \mu \mathrm{L}$ of hydrogen peroxide in $100 \mathrm{~mL}$ of $0.01 \mathrm{M}$ phosphate buffer ( $\mathrm{pH}$ 6.0) and $0.1 \mathrm{~mL}$ of enzyme preparation. The reaction was performed using a spectrophotometer at $470 \mathrm{~nm}$ for $2 \mathrm{~min}$ at $30^{\circ} \mathrm{C}$. The results were expressed in $\mathrm{D} \min ^{-1} \mathrm{mg}$ protein ${ }^{-1}$ absorbance units.

\section{Peroxidase isozymes}

For the electrophoretic analysis of peroxidase isoenzymes, $10 \mathrm{~mL}$ of the enzymatic preparation was placed on a dialysis membrane (molecular exclusion limit, 20,000) and concentrated at $4{ }^{\circ} \mathrm{C}$ with polyethylene glycol. After $2 \mathrm{~h}$, the residue on the membranes was resuspended $(0.5 \mathrm{~mL})$ in the same extraction buffer containing $10 \%$ glycerol. The protein content of the samples was determined (BRADFORD, 1976), and the content was adjusted to the same amount for further electrophoresis. A sample was obtained from the mycelium of $E$. turcicum grown in liquid $\mathrm{LCH}$ medium under constant shaking at $25^{\circ} \mathrm{C}$ in the dark for 14 days. The procedure for the extraction of fungal peroxidases was the same as that for the extraction of plant peroxidases.

Anodic polyacrylamide gel electrophoresis was performed using Bio-Rad vertical electrophoresis equipment (Mini Protean II). Polyacrylamide gels at 4\% (concentrator gel) and $10 \%$ (running gel) were used. Tris-glycine $(\mathrm{pH} 8.9)$ was used as the running buffer. As the running dye, $0.25 \%$ bromophenol blue was used. After loading the samples, the plate was maintained at $4^{\circ} \mathrm{C}$ under a constant voltage of $80 \mathrm{~V}$ until the end of the run. To visualize the peroxidase bands, the gel was immersed for $30 \mathrm{~min}$ in $100 \mathrm{~mL}$ of $0.1 \mathrm{M}$ sodium acetate buffer ( $\mathrm{pH} 5.0$ ) containing $3.3 \mathrm{mM}$ guaiacol and $1 \mathrm{~mL}$ hydrogen peroxide. After staining, the gel was fixed in $7 \%$ acetic acid for $15 \mathrm{~min}$ and stored in distilled water.

\section{Histology}

For histological analysis, corn leaf epidermis was removed with a razor blade at indicated intervals after pathogen inoculation $(0,3,6,9,12,15,18,24$, $36,48,72$, and $120 \mathrm{~h}$ ) and blushed for $3 \mathrm{~min}$ with $o$-toluidine blue (O'BRIEN; FEDER; McCULLY, 1964), as indicative of lignification, for microscopic observation. Thereafter, excess dye was removed using distilled water, and the material was mounted in $20 \%$ glycerol on a slide for observation under an optical microscope. Moreover, cross-sections were obtained using a razor blade from samples collected at 12 days after inoculation to verify the presence of fungal mycelia inside the xylem vessels.

According to the methodology described above, inoculated and non-inoculated plant tissue samples were also collected at 12 days after pathogen inoculation for electron microscopy. The samples were fixed in FAA (formaldehyde:acetic acid:50\% ethanol, 5:5:90, v/v/v) for $48 \mathrm{~h}$ and then transferred to $60 \%$ and $70 \%$ ethanol. The samples were cross-sectioned with a razor blade and dehydrated in a gradual series of alcohol $(80 \%, 90 \%$, and three times in $100 \%$ ) for $30 \mathrm{~min}$ in each concentration. Then, the material was dried in a critical drying apparatus (Balzers CPD 030) with $\mathrm{CO}_{2}$, mounted on stubs with double-sided carbon tape, metallized with evaporator gold (MED 010 Balzers Union) for $150 \mathrm{~s}$, and observed under a scanning electron microscope (DSM 940A Zeiss) at an acceleration of $10 \mathrm{kV}$.

\section{RESULTS AND DISCUSSION}

Figure 2 illustrates the development of $E$. turcicum in plant tissues following inoculation with spore suspension at a concentration of $5 \times 10^{4}$ conidia $\mathrm{mL}^{-1}$. With suspensions at concentrations of $5 \times 10^{1}, 5 \times 10^{2}$, and $5 \times 10^{3}$ conidia $\mathrm{mL}^{-1}$, conclusive results could not be obtained due to the reduced number or even the absence of conidia in the sampled tissues.

The percent germination of conidia was almost equal on the resistant and susceptible genotypes, with the maximum value of approximately $80 \%$ at $24 \mathrm{~h}$ after inoculation. Although appressorium formation was $13 \%$ higher in the resistant genotype than in the susceptible genotype at $12 \mathrm{~h}$ after inoculation, it is interesting to note that there was a delay in pathogen penetration in the former at $18 \mathrm{~h}$ after inoculation. Specifically, at $18 \mathrm{~h}$ after inoculation, pathogen penetration in the resistant genotype was $16 \%$ lower than that in the susceptible one, but the values were comparable at 12 and $24 \mathrm{~h}$, suggesting a delay of approximately $12 \mathrm{~h}$. This finding is very important, because the size of the infection site may be linked to the spatiotemporal diffusion of substances within the tissues or preformed defense mechanisms, such as lignification. Direct penetration into corn leaves through the formation of appressoria on the leaf surface and subcuticular penetration pegs is typical of E. turcicum (KNOX-DAVIES, 1974). 

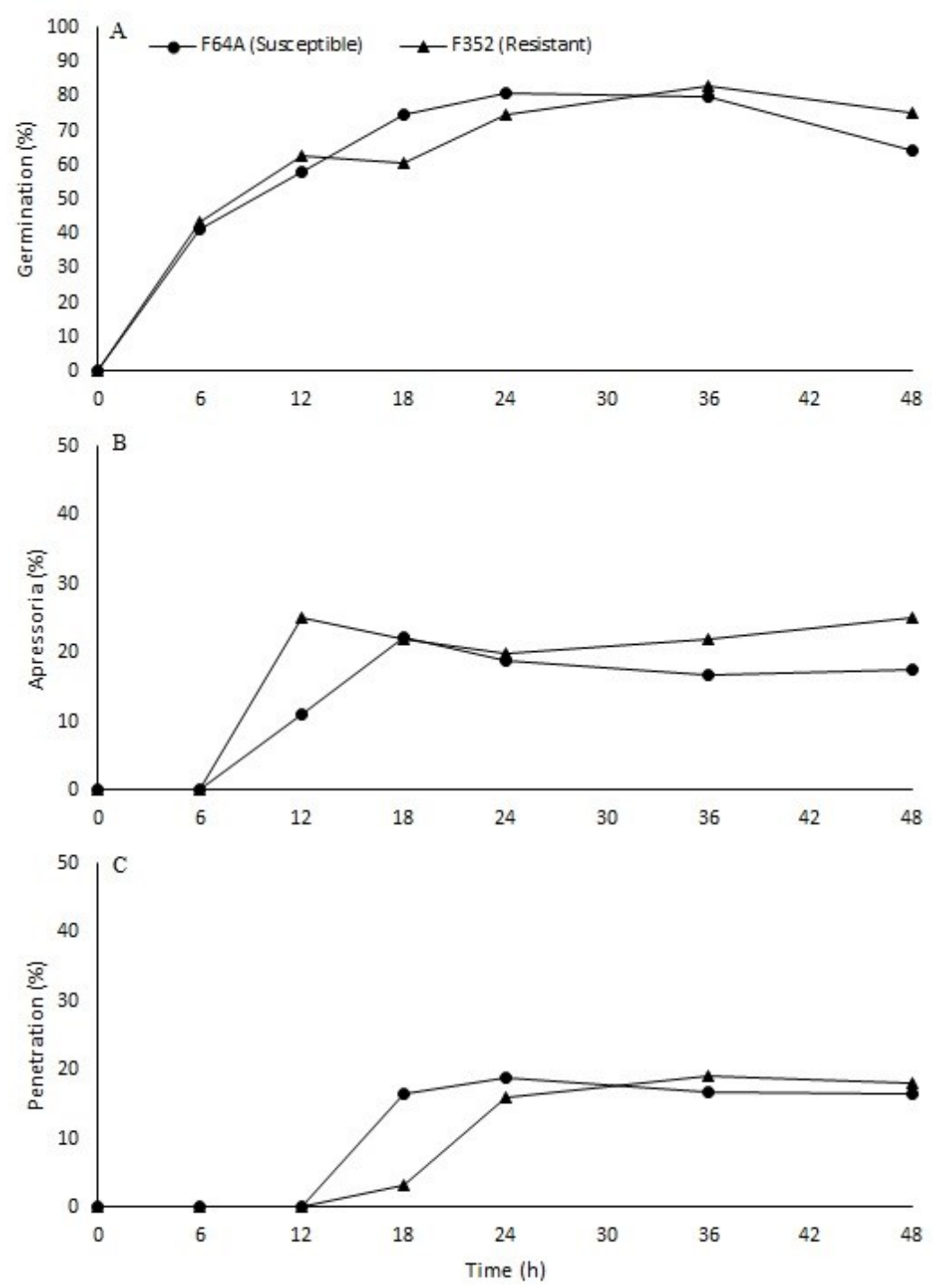

Figure 2. Germination (A), formation of apressoria (B) and penetration (C) of E. turcicum conidia, inoculated in the concentration of $5 \times 10^{4}$ conidia $\mathrm{mL}^{-1}$, in maize leaves of susceptible F64A $(\bullet)$ and resistant F352 ( $\left.\mathbf{\Delta}\right)$ genotypes.

The growth kinetics of lesions and number of lesions and chlorotic points resulting from pathogen penetration into the leaves are shown in Figure 3. In both susceptible and resistant genotypes, the first symptoms appeared $24 \mathrm{~h}$ after inoculation in the form of chlorotic points, with an area of approximately $0.25 \mathrm{~mm}^{2}$ (Figures $3 \mathrm{~A}$ and $3 \mathrm{C}$, respectively).

There were no differences in the expansion of chlorotic points after 14 days between the genotypes, and this remained true for all other points that were not marked. However, in the susceptible genotype, 11 days after inoculation, necrotic lesions appeared in regions where no chlorotic points were observed. These relatively large lesions (80 times larger than the chlorotic points) showed a very high growth rate. Three necrotic lesions on the inoculated leaves were observed (Figure 3B). The presence of chlorotic points and, particularly, necrotic lesions characterizes the susceptibility of the genotype F64A to E. turcicum. The number of chlorotic points on inoculated leaves (Figures 3B and 3D) was almost the same in both genotypes, which is consistent with the percent of penetration of the fungus into the host tissues (Figure 2C).

The fact that necrotic lesions in the susceptible genotype appeared in leaf regions that had not been previously marked, made it difficult to characterize the site of infection from the initial moment of inoculation to the onset of symptoms, since it could not be determined which penetration points were responsible for the formation of the lesions. To work around this problem, the inoculation microchambers whose results are illustrated in Figure 4 were used. 

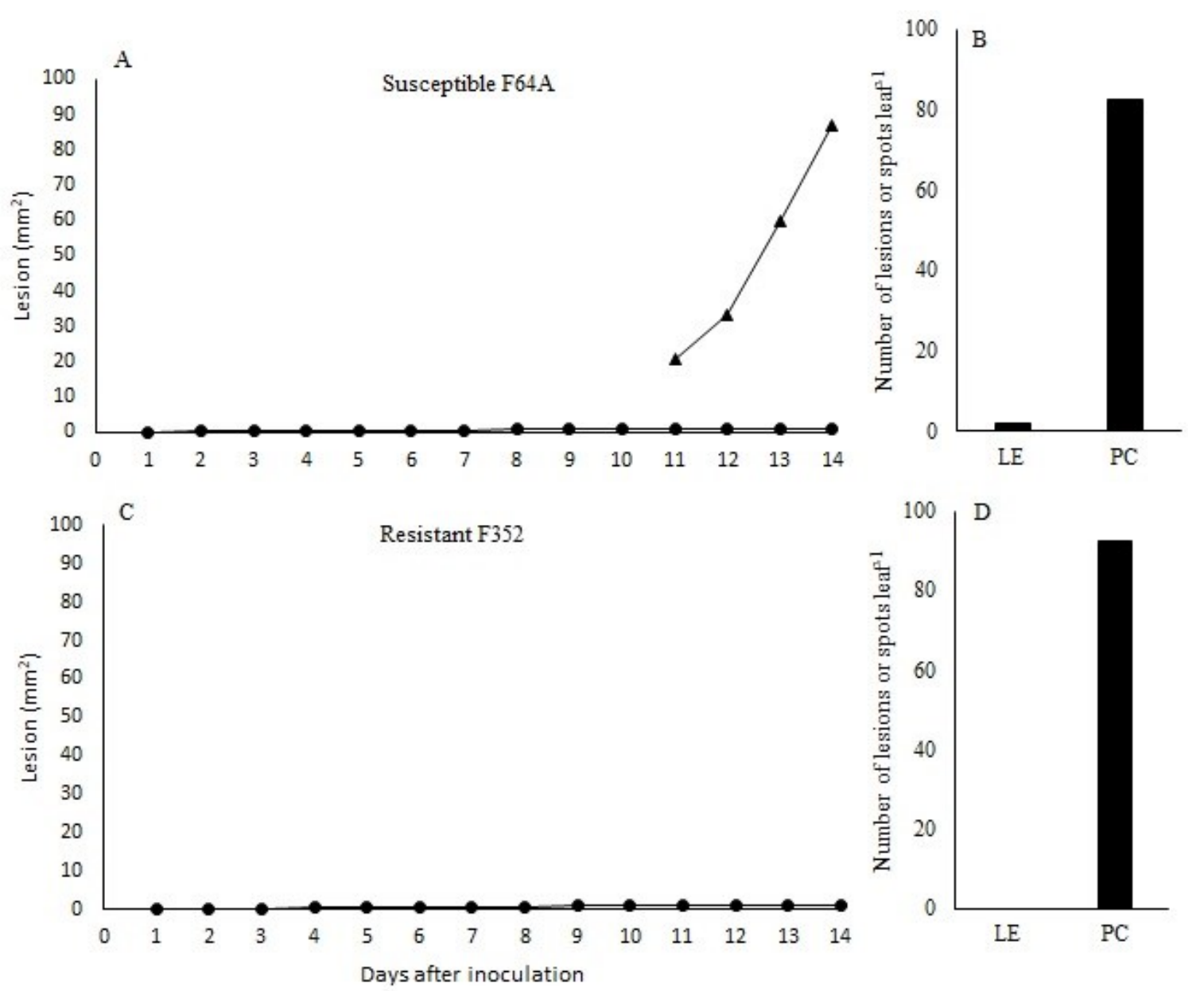

Figure 3. Growth kinetics of lesions caused by E. turcicum $\left(5 \times 10^{4}\right.$ conidia $\left.\mathrm{mL}^{-1}\right)$ in leaves of susceptible F64A (A and B) and resistant F352 maize genotypes (C and D). In (B) and (D) are represented the number of lesions (LE) and/or chlorotic points (PC) formed in the leaves 14 days after inoculation. (A) $\bullet$ indicates chlorotic points and $\boldsymbol{\Delta}$ indicates necrotic lesion.
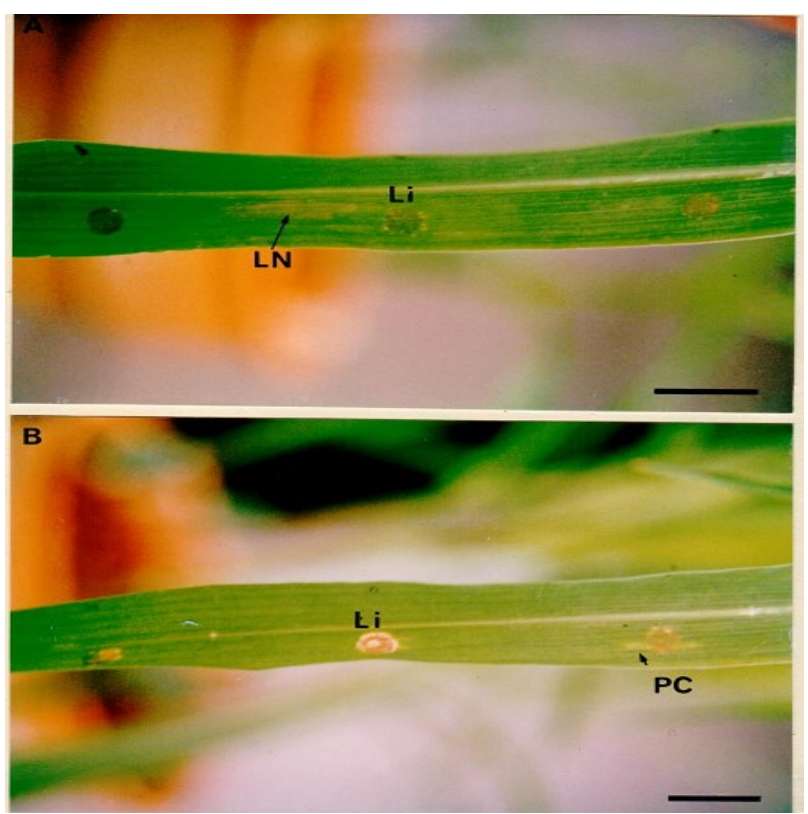

Figure 4. Symptoms resulting from inoculation with E. turcicum in susceptible F64A (A) and resistant F352 (B) maize genotypes, through a microchamber of inoculation. LN: necrotic lesion; PC: chlorotic points; Li: inoculation site. Bar $=1$ $\mathrm{cm}$. 
Although the inoculum was placed in predefined regions of the leaves, the necrotic lesions emerging in the susceptible genotype 11 days after inoculation were not close to the inoculum deposition points or chlorotic points observed in these regions. In some cases, these lesions were as long as $10 \mathrm{~mm}$ farther from the site of inoculum deposition. Meanwhile, in the resistant genotype, only chlorotic points were formed, similar to those observed when all leaves were inoculated (Figures $3 \mathrm{~A}$ and $3 \mathrm{C}$ ).
The spores were derived exclusively from the inoculum suspension, as there was no inoculum leakage from microchamber wells at the time of deposition; thus, in the susceptible genotype, the fungus penetrated the leaf and grew inside the tissues until the collapse of the colonized areas upon lesion development. Optical (Figure 5) and electronic microscopy (Figure 6) revealed the presence of fungal hyphae inside the xylem tracheal elements, which explains the appearance of lesions in the susceptible genotype at locations away from the inoculation points.

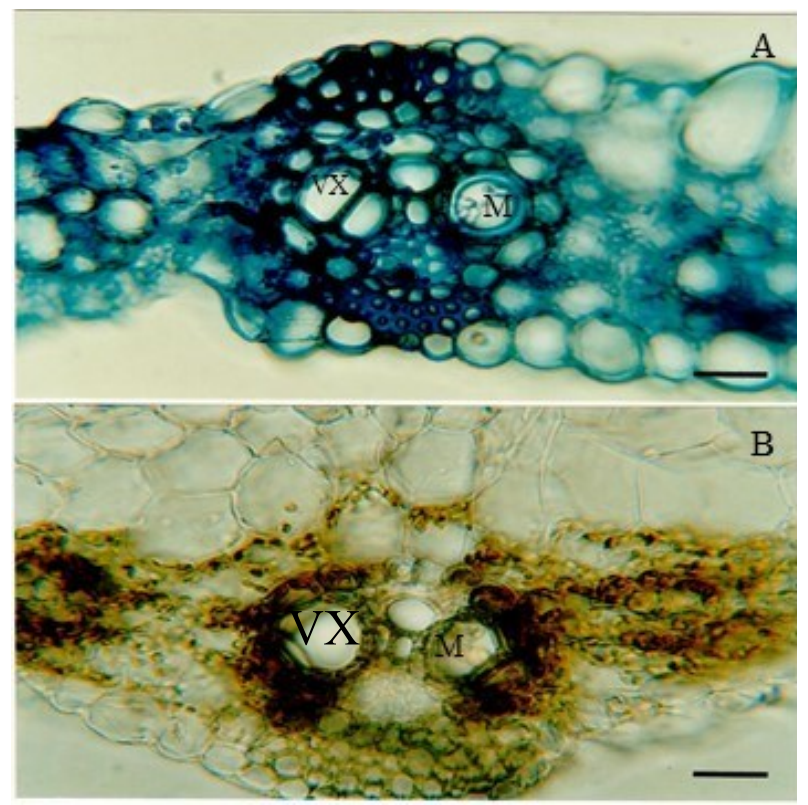

Figure 5. Cross-sections of corn leaves susceptible F64A to E. turcicum, showing the presence of mycelium (M) inside the xylem vessels (VX), 12 days after inoculation. Photographs taken under optical microscope. (A): colored material with $o$ toluidine blue; (B): non-colouring material. $\mathrm{Bar}=25 \mu \mathrm{m}$.
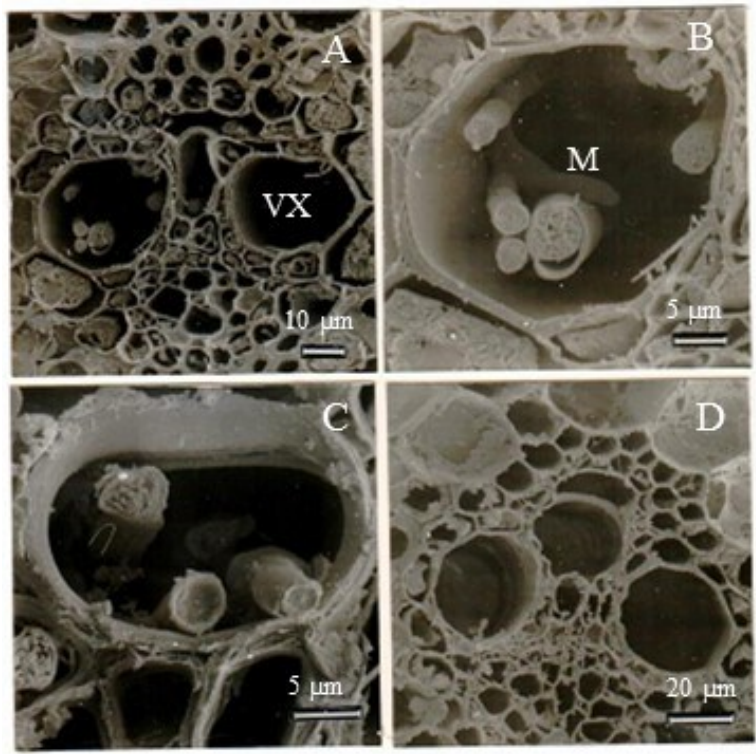

Figure 6. Cross-sections of corn leaves collected 12 days after inoculation with E. turcicum, showing the presence of mycelium (M) inside the xylem vessels (VX). (A) and (B): susceptible genotype F64A (1050X and 2600X, respectively); (C): resistant genotype F352 (3300X); (D): susceptible uninoculated genotype (775X). Scanning electronic micrograph. 
Hilu and Hooker (1964) reported that E. turcicum growth in resistant maize genotypes was restricted to a small area of mesophilic tissue, even though the fungus penetrated the xylem tissue. Meanwhile, in susceptible genotypes, fungal hyphae penetrated and rapidly grew through the xylem vessels, subsequently colonizing the mesophilic tissues and producing necrotic lesions. Likewise, in sorghum leaves, Stangarlin et al. (1994) confirmed the presence of E. turcicum hyphae inside the xylem tracheal elements a dead tissue through which the fungus could develop avoiding the activation of the plant's defense mechanisms.

Kotze et al. (2018) verified that at 9 days after inoculation, corn leaf tissue in the regions of necrotic lesions had collapsed, and E. turcicum hyphae were present in the xylem vessels and tracheids, blocking almost $75 \%$ of channels. In this pathosystem, mesophilic necrosis may have occurred because of the production of monocerin toxin by E. turcicum (CUQ et al., 1993).

Of note, in the resistant genotype, fungal hyphae were present inside the xylem elements (Figure 6C). However, there was delay in the penetration of the fungus in the resistant genotype, and the expression of other plant defense mechanisms, such as lignification, and symptoms manifested only in the form of chlorotic points were observed. Similarly, Trese and Loschke (1990) confirmed the presence of E. turcicum mycelium in the xylem vessels of maize plants under both compatible and incompatible interactions, although there were no differences in fungal growth between the two types of interaction at 3 days after infection. The authors also described two types of infection sites; in the first type, only small vessels were colonized by the mycelium, whereas in the second type, both small and large vessels were colonized. Moreover, in the second type, colonization occurred only in $16 \%$ of the infection sites, which was responsible for the formation of lesions. According to Levy (1991), the frequency of E. turcicum infection (percentage of inoculated sites that develop lesions) on corn can range from $17 \%$ to $95 \%$, depending on environmental conditions, host genotype, and pathogen variability.

E. turcicum may form hemibiotrophic interactions with corn, because only limited damage occurs and the incubation period is long without visible symptoms during the early stages of infection, whereas necrotic lesions develop in the late stages of infection (WU; TURGEON, 2013).
Thus, E. turcicum initially acts as a biotroph, but following germination and growth as an epiphyte on the leaf surface, it penetrates the epidermal cells and grows intercellularly through the xylem vessels without killing the cells. Subsequently, with extensive colonization of the xylem elements, the mesophilic cells gradually die due to profuse colonization and toxin release, making the fungus necrotrophic (KOTZE et al., 2018).

Figure 7 shows the peroxidase activity as a function of time in the susceptible and resistant genotypes as well as the percent activity in the diseased tissues of infected genotypes relative to that in inoculated or uninoculated controls.

Both genotypes showed very similar behavior, with marked increase in peroxidase activity from $18 \mathrm{~h}$ of inoculation, coinciding with the time at which the highest percentage of appressorium formation was observed (Figure 2B). These results are consistent with those reported by Cadena-Gomez and Nicholson (1987), who noted a strong increase in the activity of this enzyme from the time of higher percentage of appressorium formation in the leaves of corn susceptible and resistant to Helminthosporium maydis. Southerton and Deverall (1990) noted similar increases in peroxidase activity during the formation of the first haustorium by the virulent and avirulent isolates of Puccinia recondita f. sp.. tritici in resistant wheat cultivars.

Peroxidase is the final enzyme in the lignin biosynthetic pathway. In the present study, histochemical analyses did not reveal lignification in the susceptible genotype (data not shown), even though it exhibited peroxidase activity similar to the resistant genotype. However, lignin deposition was observed near the pathogen penetration points in samples collected at 24 and $48 \mathrm{~h}$ after inoculation (Figure 8). In resistant and susceptible maize leaves stained with $o$-toluidine blue, Angra-Sharma and Sharma (1994) did not find lignification in either genotype infected with Helminthosporium maydis.

At 12 days after inoculation (Figure 9), there were practically no differences in enzymatic activity between the AS and TV regions of both genotypes. In the susceptible genotype, the higher activity observed in the HA region likely contributed to the containment of lesions (LE region). The highest activity was noted in the $\mathrm{CP}$ region of the susceptible genotype, which may explain the non-growth of these points or even the non-formation of lesions from these chlorotic points. 

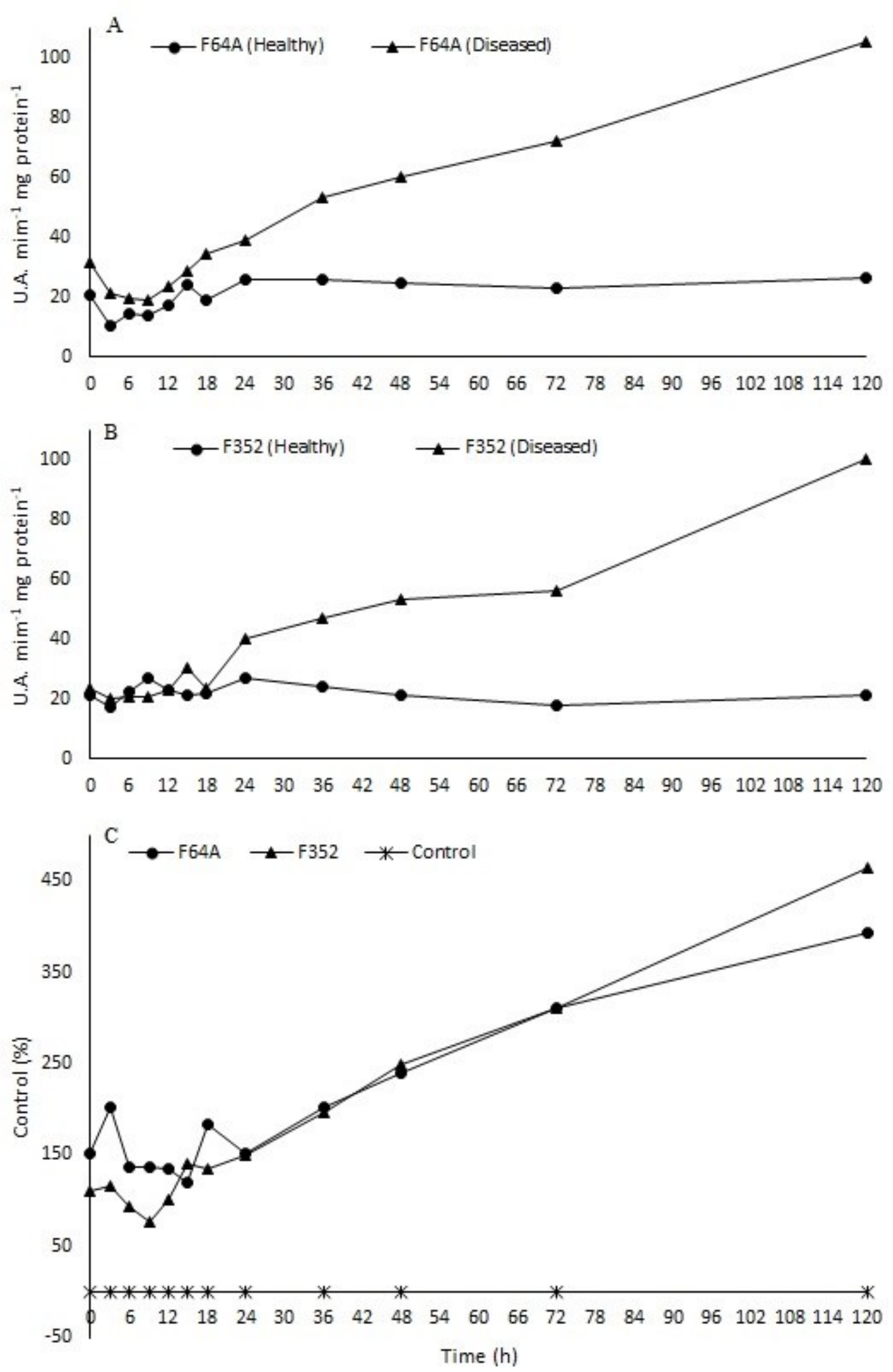

Figure 7. Peroxidase activity in corn leaves of susceptible F64A (A) and resistant F352 (B) genotypes to E. turcicum. Samples collected at intervals of time after inoculation with $5 \times 10^{4}$ conidia $\mathrm{mL}^{-1}$. In $(\mathrm{C})$ is represented the enzymatic activity in inoculated tissues in relation to non-inoculated healthy tissues (control). 


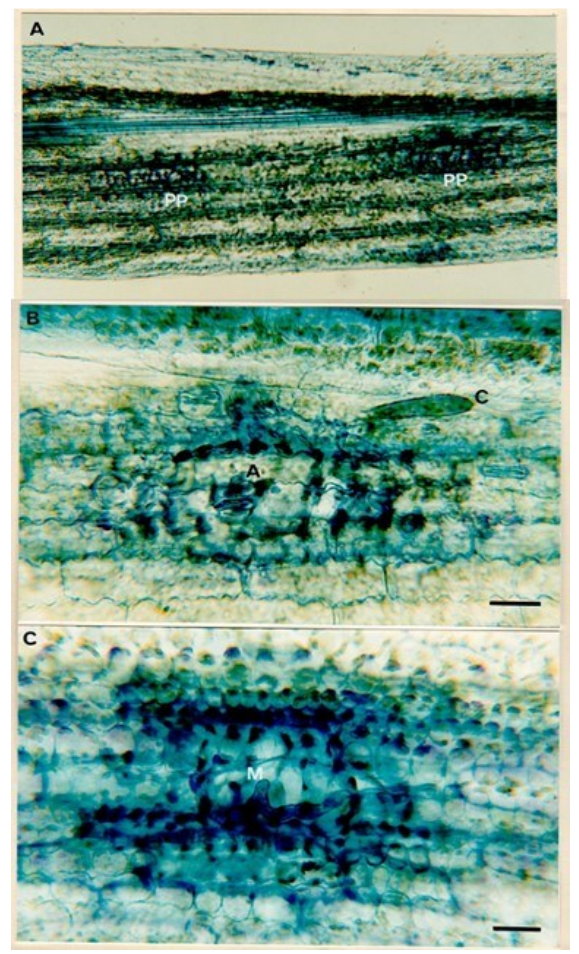

Figure 8. F352 resistant corn leaves inoculated with $5 \times 10^{4}$ conidia $\mathrm{mL}^{-1}$ of E. turcicum, exhibiting lignification regions. (A): pathogen penetration points (PP); (B): detail of a penetration point showing conidium (C) and apressorium (A). (C): mycelium (M) in the tissues of the plant. Samples collected 24 and $48 \mathrm{~h}$ after inoculation in (A) and (C), respectively. Lignification represented by blue coloring. Photograph taken under optical microscope. Bar $=25 \mu \mathrm{m}$.

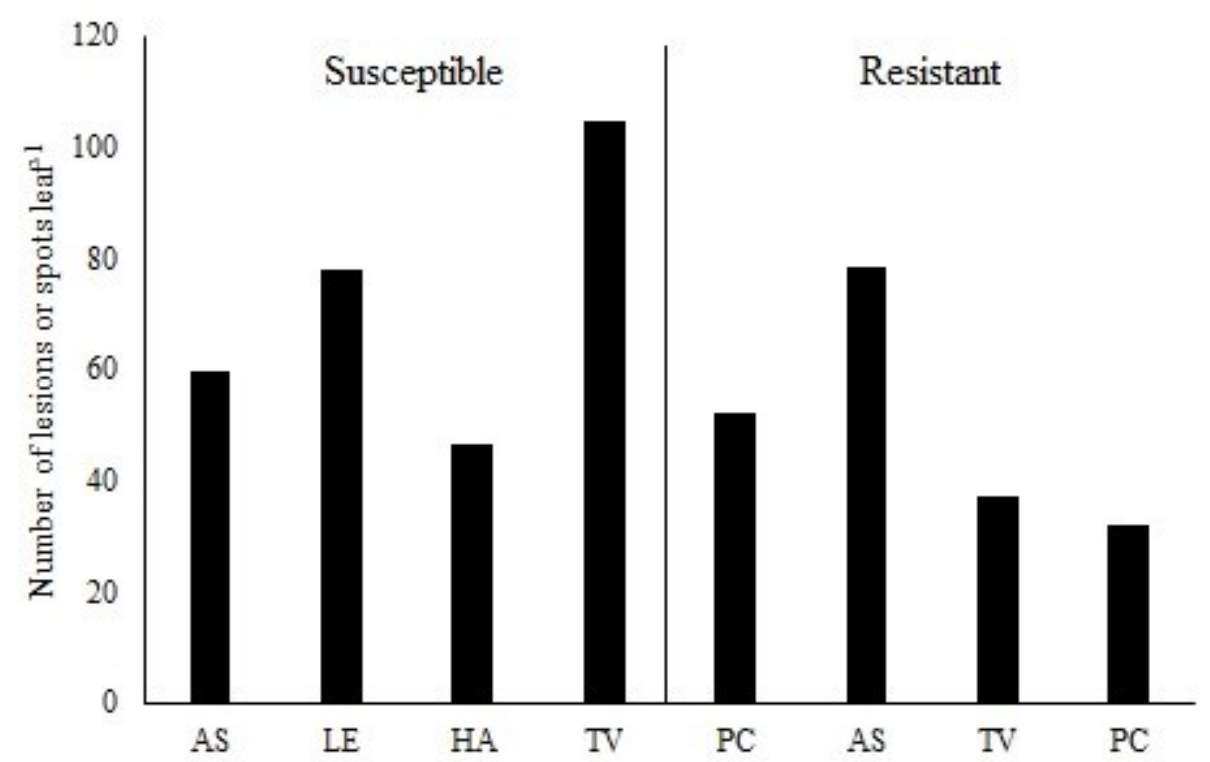

Figure 9. Peroxidase activity in corn leaves of susceptible (F64A) and resistant (F352) genotypes to E. turcicum. Samples collected 12 days after inoculation with $5 \times 10^{4}$ conidia $\mathrm{mL}^{-1}$ of the pathogen. The different regions sampled corresponded to: healthy tissue of uninoculated leaf (AS), distant green tissue from lesions and/or chlorotic spots (VT), chlorotic spots (PC), necrotic lesions (LE) and green tissue $2 \mathrm{~mm}$ wide adjacent to necrotic lesions (HA).

The electrophoretic pattern of peroxidases (Figure 10) showed the presence of three isoenzymes, with the Reichert Meissl (RM) values of $0.14,0.18$, and 0.22 , in all sampled regions. In the $\mathrm{HA}, \mathrm{LE}$, and CP regions (the latter in both resistant and susceptible genotypes), two additional isoenzymes with the RM values of 0.25 and 0.27 were identified. The higher peroxidase activity in the HA, LE, and CP regions (Figure 9) was associated with the higher concentrations of isoenzymes in 
these tissues, as shown in the densitometry graphs (Figure 10B). No peroxidase isoenzyme was detected in the fungal mycelium extract. Therefore, the electrophoretic patterns of and peroxidase activity in the $\mathrm{HA}$, LE, and $\mathrm{CP}$ regions were attributed solely to the isoenzymes produced by the host plant. In a study on maize and E. turcicum, Shimoni, Bar-Zur, and Reuveni (1991) identified six isoenzymes, three of which were present in the uninfected resistant genotype but not in the susceptible genotype.
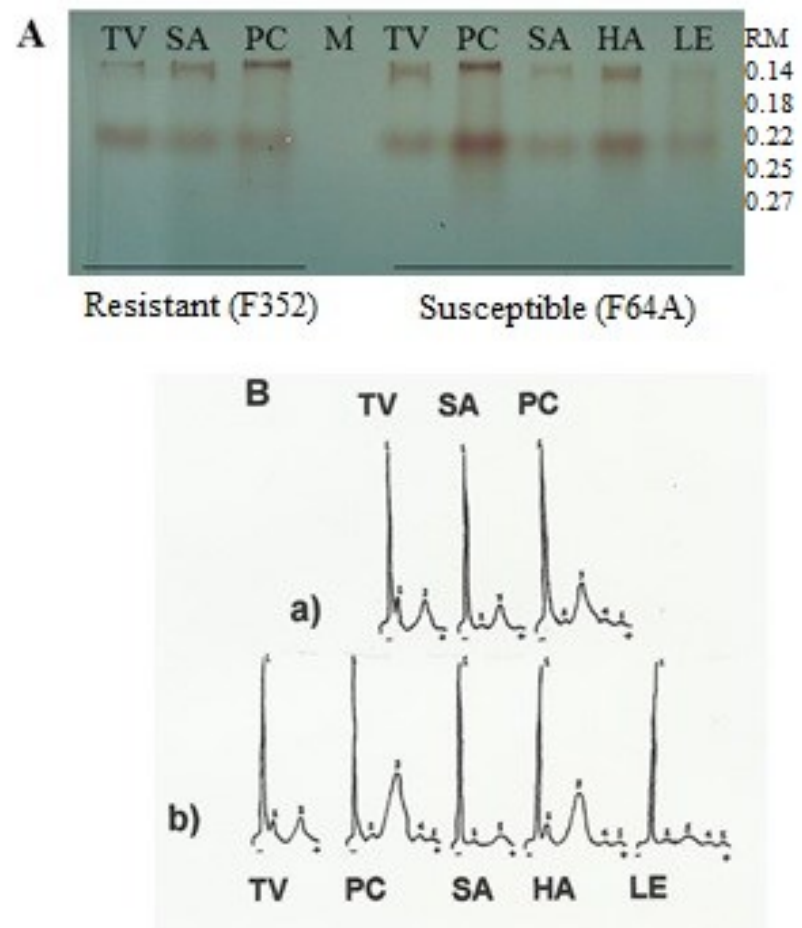

Figure 10. (A): Anodic electrophoresis in polyacrylamide gel of susceptible and resistant corn leaf extract E. turcicum. Samples collected 12 days after inoculation with $1 \times 10^{4}$ conidia $\mathrm{mL}^{-1}$. Gel with guaiacol for visualization of peroxidase isoenzymes. Sampled regions: uninoculated leaf healthy tissue (SA), green tissue distant from lesions and/or chlorotic spots (TV), chlorotic spots (PC), necrotic lesions (LE) and green tissue $2 \mathrm{~mm}$ wide adjacent to necrotic lesions (HA). M: pathogen mycelium extract. (B): Electrophoretic pattern represented by densitometry (405 $\mathrm{nm}$ filter), where the numbers represent the individual bands (a: resistant genotype; b: susceptible genotype).

In the various regions sampled from corn leaves, specifically in the TV region (Figure 9), peroxidase activity was higher in the susceptible genotype than in the resistant genotype. Reuveni and Ferreira (1985) reported that the rate of increase in peroxidase activity in the leaves and roots of tomato infected with Verticillium dahliae was higher in susceptible plants than in resistant plants. Shimoni, Bar-Zur, and Reuveni. (1991) detected higher peroxidase activity in resistant corn material than in the susceptible one before E. turcicum inoculation. At 6 days after inoculation, peroxidase activity increased in both materials, although the lesions occurred after 4 days.

According to Bastiaans (1991), the photosynthetic activity of diseased leaves is suppressed due to reduction in the green area at the site of visual lesions and alteration of metabolism in the remaining green area; this seemingly healthy region, albeit with altered photosynthesis, is called a virtual lesion. Similarly, Levy and Leonard (1990) noted reduction in the photosynthetic efficiency of maize plants infected with E. turcicum due to the destruction of photosynthetic leaf tissue and decrease in $\mathrm{CO}_{2}$ assimilation in leaf tissue adjacent to the lesion.

Overall, in the present study, in addition to the visual lesions represented by necrotic areas and chlorotic spots, which reduce photosynthesizing green tissue, other seemingly healthy regions with altered metabolism were noted in both susceptible and resistant genotypes. In particular, regions of green tissue distant from the necrotic lesions or chlorotic spots and green tissue around the necrotic lesions showed increased peroxidase activity, indicating altered gene expression patterns. This alteration may lead to the synthesis of specific compounds that would directly or indirectly alter carbohydrate metabolism, which is responsible for providing energy for metabolic reactions. 


\section{CONCLUSIONS}

In the resistant corn genotype (F352) infected with E. turcicum, the primary infection site is characterized by chlorotic point-like symptoms resulting from pathogen penetration into the xylem vessels and restriction of fungal colonization in the surrounding mesophilic tissues. Meanwhile, in the susceptible corn genotype (F64A) infected with $E$. turcicum, two types of infection site are present. In the first one, or the primary infection site, represented by chlorotic spot-like symptoms, the pathogen penetrates the xylem vessels and moderately colonizes the mesophyll tissue as a function of lignification. Following the formation of the primary infection site, the pathogen grows inside the xylem vessels and profusely colonizes mesophyll tissues farther from the penetration site, resulting in the formation of the secondary infection site and development of necrotic lesions.

\section{REFERENCES}

ALTAF, M. Study on the response of different maize cultivars to various inoculum levels of Bipolaris maydis (Y. Nisik \& C. Miyake) shoemaker under field conditions. Journal of Entomology and Zoology Studies, 4: 533-537, 2016.

ANGRA-SHARMA, R.; SHARMA, D. K. Biochemical and histological studies on susceptible and resistant maize leaves infected by Helminthosporium maydis. Plant Pathology, 43: 972-978, 1994.

BASTIAANS, L. Ratio between virtual and visual lesion size as a measure to describe reduction in leaf photosynthesis of rice due to leaf blast. Phytopathology, 81: 611-615, 1991.

BERGER, R. D., BERGAMIN FILHO, A.; AMORIM, L. Lesion expansion as an epidemic component. Phytopathology, 87: 1005-1013, 1997.

BERGSTROM, G. C.; NICHOLSON, R. L. Microhumidity chamber for quantitative inoculation of attached corn leaves with fungal pathogens. Phytopathology, 73: 1040-1042, 1983.

BRADFORD, M. A rapid and sensitive method for the quantification of microgram quantities of protein utilizing the principle of protein-dye binding. Analytical Biochemistry, 72: 248-254, 1976.

CADENA-GOMEZ, G.; NICHOLSON, R. L. Papilla formation and associated peroxidase activity: a nonspecific response to attempted fungal penetration of maize. Physiological and Molecular Plant Pathology, 31: 51-67, 1987.

CARVALHO, R. V.; PEREIRA, O. A. P.; CAMARGO, L. E. A. Doenças do milho. In: AMORIM, L.; REZENDE, J. A. M.; BERGAMIN FILHO, A.; CAMARGO, L. E. A. (Eds.). Manual de fitopatologia: Doenças das plantas cultivadas. 5. ed. Ouro Fino, MG: Ceres, 2016. v. 2, cap. 57, p. 549 -560 .

CONAB - Companhia Nacional de abastecimento. Acompanhamento da Safra Brasileira - Grãos. Monitoramento agrícola - Safra 2019/20, v. 7. n. 8. Brasília, DF: CONAB, 2020. 66 p.

COSTA, L. V.; SILVA, D. D.; COSTA, R. V. Helmintosporiose causada por Exserohilum turcicum na cultura do milho. 1. ed. Sete Lagoas, MG: Embrapa, 2013. 8 p. (Circular Técnica, 195).

CUQ, F. et al. Monocerin in Exserohilum turcicum isolates from maize and a study of its phytotoxicity. Phytochemistry, 34: 1265-1270, 1993.

FERGUSON, L. M.; CARSON, M. L. Temporal variation in Setosphaeria turcica between 1974 and 1994 and origin of races 1,23, and 23N in the United States. Phytopathology, 97: 1501-1511, 2007.

FAO - Food and Agriculture Organization. Production: crops. 2020. Disponível em: $<$ www.fao.org/faostat>. Acesso em: 20 mai. 2020.

HAMMERSCHIMIDT, T. R.; NUCLES, E. M.; KUC, J. Association of enhanced peroxidase activity with induced systemic resistance of cucumber to Colletotrichum lagenarium. Physiological Plant Pathology, 20: 73-82, 1982.

HILU, H. M.; HOOKER, A. L. Host-pathogen relationship of Helminthosporium turcicum in resistant and susceptible corn seedlings. Phytopathology, 54: 570-575, 1964.

KNOX-DAVIES, P. S. Penetration of maize leaves by Helminthosporium turcicum. Phytopathology, 64: 1468-1470, 1974.

KOTZE, R. G. et al. A histological assessment of the infection strategy of Exserohilum turcicum in maize. Plant Pathology, 68: 504-512, 2018.

LEVY, Y. Variation in fitness among field isolates of Exserohilum turcicum in Israel. Plant Disease, 75: 163-166, 1991.

LEVY, Y.; LEONARD, K. J. Yield loss in sweet corn in response to defoliation or infection by 
Exserohilum turcicum. Journal of Phytopathology, 128: 161-171, 1990.

MENEGON, A. P., FORCELINI, C. A.; FERNANDES, J. M. C. Expansão de lesão por manchas foliares em cevada e sua interação com a aplicação foliar de fungicidas. Fitopatologia Brasileira, 30: 134-138, 2005.

O'BRIEN, T. P.; FEDER, N.; McCULLY, M. E. Polychromatic staining of plant cell walls by $o$ toluidine blue. Protoplasma, 59: 368-373, 1964.

PASCHOLATI, S. F.; DALIO, R. J. D. Fisiologia do parasitismo: como as plantas se defendem dos patógenos. In: AMORIM, L.; REZENDE, J. A. M.; BERGAMIN FILHO, A. (Eds.). Manual de Fitopatologia: Princípios e conceitos. 5. ed. Ouro Fino, MG: Ceres, 2018. v. 1, cap. 35, p. 423-450.

PIRES, P. C.; FERNANDES, J. M. C.; NICOLAU, M. Modelagem do progresso temporal e do padrão espacial de lesões de ferrugem da folha em trigo. Tropical Plant Pathology, 34: 97-107, 2009.

RAMATHANI, I. et al. Disease seeverity, incidence and races of Setosphaeria turcica on sorghum in Uganda. European Journal of Plant Pathology, 131: 383-392, 2011.

REUVENI, R.; FERREIRA, J. F. The relationship between peroxidase activity and the resistance of tomatoes (Lycopersicum esculentum) to Verticillium dahliae. Phytopathologische Zeitschrift, 112: 193197, 1985.

SHIMONI, M.; BAR-ZUR, A.; REUVENI, R. The association of peroxidase activity and resistance of maize to Exserohilum turcicum. Journal of Phytopathology, 131: 315-321, 1991.

SOUTHERTON, S. G.; DEVERALL, B. J. Changes in phenylalanine ammonia-lyase and peroxidase activities in wheat cultivars expressing resistance to the leaf-rust fungus. Plant Pathology, 39: 223-230, 1990.

STANGARLIN, J. R. et al. A defesa vegetal contra fitopatógenos. Scientia Agraria Paranaensis, 10: 18-46, 2011.

STANGARLIN, J. R.; PASCHOLATI, S. F. Proteção de plântulas de milho pipoca contra Exserohilum turcicum pelo uso de Saccharomyces cerevisiae. Summa Phytopathologica, 20: 16-21, 1994.

STANGARLIN, J. R. et al. Aspectos histológicos e bioquímicos da interação Exserohilum turcicum e tecido foliar de sorgo. In: CONGRESSO BRASILEIRO DE FITOPATOLOGIA, XXVII, 1994, Itajaí. Anais... Brasília: Fitopatologia Brasileira, 1994. p. 278.

TRESE, A.; LOSCHKE, D. C. High contrast resolution of the mycelia of pathogenic fungi in corn tissue after staining with calcofluor and destaining with cellulase. Phytopathology, 80: 196-200, 1990.

WU, D.; TURGEON, B. G. Setosphaeria rostrata: insights from the sequenced genome of Setosphaeria turcica. Fungal Genetics and Biology, 61: 158-163, 2013. 